\title{
A City OF Migrants: Kot.A AMBON AT THE END OF THE SEVENTEENTH CENTURY
}

\author{
Gerrit J. Knaap
}

Some fifteen years ago, Kota Ambon, the capital of the Indonesian province of Maluku, commemorated its fourth centennial. Kota Ambon today is inhabited by a large Indonesian population, including Christian and Muslim Ambonese as well as Muslim immigrants from elsewhere, mainly from Sulawesi. The proportion of non-Ambonese migrants is high. The Ambonese themselves still prefer to live in the countryside, which is understandable because the city is overcrowded and living conditions are far from comfortable. The immigrant in Kota Ambon is, however, not a modern phenomenon. The city has always had a large proportion of non-Ambonese settlers.

In this article, I discuss the development of Kota Ambon in the first 130 years of its existence and demonstrate that Kota Ambon developed into a non-Ambonese city, situated in an Ambonese countryside. ${ }^{1}$ In recent years, the "early" colonial city in Southeast Asia has been a topic of increasing interest to historians. In this respect, Kota Ambon should not be overlooked, not only because it was one of the first colonial cities but also because the archival sources allow a systematic analysis of matters in greater detail than has yet been possible for settlements elsewhere. The physical appearance of the town, its institutions and government, and its economic and demographic structure will be compared with the results of other research that has been published in the last decade. Kota Ambon, although it had several features in common with other early colonial cities, also possessed unique characteristics of its own.

Like many other cities in the world, Kota Ambon originated from a settlement outside the walls of a fortress. This fortress was founded in 1576 by the Portuguese, who needed a new stronghold after they were expelled from the island of Ternate in the North Moluccas by Sultan Baab Ullah in 1575. The new fortress was situated on Honibopo beach, which was part of the territory of the village of Ahusu, one of the Ambonese allies of the Portuguese. It was constructed from stone and named "Nossa Senhora da Anunciada." Around the

1 All archival sources used for this article originate from the Algemeen Rijksarchief (ARA) in The Hague, in particular from the collection of the Verenigde Oost-Indische Compagnie [abbreviated hereafter as VOC]. The abbreviation "res." refers to a resolution of the Political Council in the province of Ambon. "Zielsbeschr." refers to "zielsbeschrijving" (description of souls) and "dagregister Victoria" to the daily register kept in Castle Victoria. 
fortress casados, former Portuguese soldiers who had married in Asia and had chosen to stay there, settled. In times of crisis, they served as a militia to assist the garrison of the Portuguese Crown against its opponents. Besides the casados, several Christian Ambonese villages supportive of the Portuguese cause had grown up near the fortress for protection against attack from the Ternatan-led anti-Portuguese Muslim coalition. One of these villages consisted of orang merdeka, Asian Christians, who had followed the Portuguese from the North Moluccas to Ambon in 1575. These orang merdeka may have been indigenous North Moluccans, but it is also possible that they were former slaves who had been given their freedom by their masters; orang merdeka means "free people."2

The settlement witnessed a constant state of war in the first three decades of its existence. It sustained serious attacks in 1591, 1593, and 1598. The opponents usually were Ambonese Muslims, who received considerable backing from Ternatan and/or Javanese forces. In 1600, the Muslims were also assisted by Dutch ships under the command of Steven van der Haghen. The Dutch had come to Ambon in search of spices, in particular cloves. On each of these occasions the Portuguese held their position, but on February 23, 1605, when Steven van der Haghen returned on behalf of the "Verenigde Oost-Indische Compagnie" (VOC), the Dutch East India Company, accompanied by a fleet of ten ships, the desperate governor, Gaspar de Melo, surrendered the fortress and all its dependencies in the Central Moluccas to the Dutch. On this occasion, the Dutch, for the first time since they had arrived in Asia, acquired sovereign rights, and as such the acquisition of the Ambon fortress marked the beginning of their colonial empire. ${ }^{3}$

Although Steven van der Haghen guaranteed freedom of religion to the Catholic Portuguese, this tolerance did not last long. In March 1605, the Portuguese governor, together with several of his officials, soldiers, and their families, a group several hundred strong, sailed in two ships to Melaka. The following May, 250 of the remaining Portuguese, including the Jesuit missionaries and perhaps some orang merdeka, also had to leave, in this case for the Philippines. Altogether, approximately 600 Portuguese inhabitants had to leave. Only 46 Portuguese-influenced Asian or mestizo families pledged their allegiance to the Dutch and stayed behind, i.e. approximately $200-300$ persons in all.4

A preindustrial European "city," in modern terminology, is considered to be a phenomenon to which some spatial, economic, judicial, and institutional characteristics can be ascribed. Generally, a city is labeled as a settlement that (1) is rather crowded and enclosed with walls and/or ditches for its defense, (2) has a population with mainly nonagrarian specializations that to a certain extent dominates the surrounding countryside, (3) has a population whose judicial status contrasts to that of the inhabitants of the countryside, particularly in the sense that a city dweller has more rights or privileges than a villager, and (4) is a political entity with self-governing institutions that have reached a fairly high degree of

\footnotetext{
2 H.Th.M. Jacobs, "Wanneer werd de stad Ambon gesticht? Bij een vierde eeuwfeest," Bijdragen tot de Taal-, Landen Volkenkunde 131 (1975): 447, 451, 453-54, 456-57.

3 H.Th.M. Jacobs, "The Portuguese Town of Ambon 1576-1605," Paper presented to the Second International Seminar on Indo-Portuguese History, Lisbon, October 1980, p. 11; G. J. Knaap, Kruidnagelen en Christenen. De Verenigde Oost-Indische Compagnie en de bevolking van Ambon 1656-1696, Verhandelingen van het Koninklijk Instituut voor Taal- Land- en Volkenkunde 125 (Dordrecht: Foris, 1987), p. 15.

4 I. Commelin, Begin ende Voortgangh van de Vereenigde Nederlantsche Geoctroyeerde Oost-Indische Compagnie, vol. 2 , (Amsterdam: Janszoon, 1646), voyage 12, p. 36; P. A. Tiele, ed., "Documenten voor de geschiedenis der Nederlanders in het Oosten," Bijaragen en Mededeelingen van het Historisch Genootschap 6 (1883): 285, 289; H.Th.M Jacobs, ed., Documenta Malucensia, vol. 2., Monumenta Missionum Societatis Iesu 39 (Rome: Institutum Historicum Societatis lesu, 1980), pp. 681, 690.
} 
autonomy vis-à-vis the ruler of the realm. According to Anthony Reid, precolonial cities in Southeast Asia were quite different. Southeast Asian cities were settlements in which living space was not in short supply and which usually lacked walls and ditches. Its population, although heavily dependent on nonagricultural professions, had no special judicial status, and forms of self-government were limited to foreign merchants living in separate quarters of the town. ${ }^{5}$ Actually, a city was a cluster of villagelike settlements surrounding a court or a harbor.

The colonial capitals of Southeast Asia in the sixteenth and seventeenth centuries, such as Melaka, Manila, and Batavia, very much resembled European cities, with the exception of the fourth characteristic; that is, although some features of autonomy, such as self-government for certain groups of foreign merchants as in indigenous Southeast Asian cities, were found, it is obvious that the "lord of the realm," in this case the representative(s) of the Portuguese or Spanish Crown or the authorities of the VOC, dominated the institutions of the town.

Kota Ambon fits into this adapted European pattern except for the first characteristic, the spatial one. Although Kota Ambon was a rather crowded place, situated in the coastal valley at the mouth of the Rivers Wai Gajah and Wai Tomo, it had no city walls or ditches surrounding it. Economically, the nonagricultural element was dominant in the settlement, in particular in the field of trade relations wherein it had a clear advantage over the countryside. Its population had a special judicial status when compared with the inhabitants of the villages. It consisted of servants of the VOC and "colonists" or burgers (citizens). The group of citizens, in principle at least, had to serve the state, the VOC, by forming armed militias that could assist the Company's standing army in the event of emergency. The villagers or orang negeri, on the other hand, were obliged to serve the colonial state with "compulsory services" in the sense that they had to carry Company servants, letters, and provisions, man the fleet of indigenous war vessels, the so-called hongi, and help build the Company's fortresses. ${ }^{6}$ Kota Ambon, however, was not an autonomous political entity because it had no government of its own; the city was administered by the local VOC governor and council.

These criteria excluded the villagers from being part of the city. The Ambonese villages that were found on the coastal plain of the Wai Tomo and the Wai Gajah, such as Soya di Bawah, Nusaniwe, Latuhalat, Urimesen, Halong, Amahusu, and Hatiwe, are considered to be nonurban. This label is also applied to the settlements of Mardika and Batu Merah. Mardika's population consisted of the descendants of a sixteenth-century group of orang merdeka. Although its population possessed scarcely any land, it was still obliged to perform compulsory services like all other Ambonese villages. More or less the same was true for Batu Merah, which began in 1656 as a place to hold hostage defeated Ambonese enemies of the VOC. Gradually, Batu Merah developed into a real village; its inhabitants, like those of Mardika, were considered to be orang negeri and not citizens. ${ }^{7}$

\section{Appearance of the City}

The most outstanding building in Kota Ambon, which dominated one's outlook when approaching the town by sea or by land, was the castle. Throughout VOC rule in Ambon,

\footnotetext{
5 A. Reid, "The Structure of Cities in Southeast Asia, Fifteenth to Seventeenth Centuries," Journal of Southeast Asian Studies 9 (1980): 240-42, 247.

6 Knaap, Kruidnagelen, pp. $138-60$.

7 Ibid., pp. 272, 301.
} 
the Dutch were busy improving the construction of the castle to keep it in a good state of defense. A full account of its building history would fill several pages; consequently, only the most important events are dealt with here. When the Dutch took over, the castle was a brick rectangle that was very vulnerable to damage by enemy gunfire. Thus in 1605-1606, it was encircled by a small ditch and small bulwarks were erected at its corners. In 1614, it received a new name, Victoria, to commemorate the seizure of Ambon from the Portuguese. In the early 1630s, the ditch was broadened and the consequent available soil was used to strengthen the fortress walls. In 1654, Victoria was enlarged on the seaside because it had become too small for the ever-growing activities of the Dutch. ${ }^{8}$

In the beginning of the 1670 s, probably because the VOC felt vulnerable confronted as it was with the war of the Netherlands against the combined forces of England and France, a discussion began about the defensive merits of the castle. They even contemplated building an entirely new castle in another place. However, on February 17, 1674, the castle and the city were struck by the most severe earthquake of the century and the castle buildings were severely damaged. As a result, the VOC had to buy a house in town to serve as a temporary residence for the governor and his family, but the temporary residence turned out to be permanent. The next major project concerning the castle began in 1679: a stone encirclement was built outside the walls, and new ditches were dug facing the landside. This encirclement, which was in turn protected by a small ditch, was completed in 1682 . In the 1680s, the question of whether a new castle should be built gained new impetus. Finally, in 1697 they definitely decided to stay at the old site. ${ }^{9}$

When the Dutch took over from the Portuguese, there were four buildings used for Christian religious purposes in the vicinity of the castle, two of which served as churches for the Ambonese village populations. Of the last two, probably wooden structures, nothing further is heard after 1605. The other two, St Paul's and the Misericordia, were obviously meant to serve the Portuguese garrison and the urban population: the first as a parish church and the second as a hospital. The Misericordia probably was a hospital under the Dutch as well until a new building was constructed for this purpose in the period 16251630. St. Paul's was turned into a Protestant Calvinist church, where sermons for both the Dutch- and the Malay-speaking congregations were read. At the end of the 1620s, however, the already shaky building fell down after a storm. On its site, a new stone building was erected to serve both congregations. Another small church must also have been built inside the castle for the garrison in the first half of the seventeenth century. A fundamental segregation between the Dutch- and Malay-speaking religious communities only came about, however, after the city church burned in the great fire of 1658 . On that occasion, the VOC decided that the ever-growing communities should each have its own place of worship. Temporarily, the Dutch-speaking community attended services in the small church of the castle while a special wooden structure was erected for the Malay community on the site of the old burned building. A new church for the Dutch was built in the 1680s, just opposite

8 G. E. Rumphius, "De Ambonsche Historie behelsende een kort verhaal," Bijdragen tot de Taal-, Land-en Volkenkunde van Nederlandsch-Indië, 64 (1910), pt. 1: 25, 82; idem, pt. 2: 74; W. Ph. Coolhaas, ed., Generale missiven van gouverneurs-generaal en raden van Indië aan Heren XVII der Verenigde Oostindische Compagnie, Rijks Geschiedkundige Publicatiën 104 (The Hague: Nijhoff, 1960), 1:35; G. J. Knaap, ed., Memories van overgave van gouverneurs van Ambon in de zeventiende en achttiende eeuw, Rijks Geschiedkundige Publicatiën, Kleine Serie 62 (The Hague: Nijhoff, 1987), p. 3.

${ }^{9}$ VOC 1293: 61r; 1300: 34r-35r, 54r, 494v res.; 1344: 127 res.; 1376: 52v; W. Ph. Coolhaas, ed., Generale missiven van gouverneurs generaal en raden van Indië aan Heren XVII der Verenigde Oostindische Compagnie, Rijks Geschiedkundige Publicatiën 134 (The Hague: Nijhoff, 1971), 4: 602-3; idem, Rijks Geschiedkundige Publicatiën 150 (The Hague: Nijhoff, 1975), 5:389, 825. 
the house of the governor in town. A new stone building replaced the wooden structure of the Malay church in 1696 at the old site. ${ }^{10}$

When the Dutch took the city in 1605, most of the inhabitants' houses were situated directly adjacent to the castle. From a military point of view, the houses stood far too near the castle. Therefore, the Dutch immediately started town planning, among other things, by moving the houses a few hundred meters southward, thus creating an open space between the castle and the town. The next change must have occurred around 1625 . The number of citizens had grown considerably and the sea had eroded a large portion of the coast. The Ambonese villages were thus obliged to move to the periphery of the coastal valley, while the urban citizens gradually had to fill in the space between these villages on the one hand and the castle and seashore on the other. At the end of the seventeenth century, Kota Ambon's street pattern had reached its final structure, which can still be traced today. Olifantsstraat (Elephant Street), which went from the castle southeast toward the mountains, corresponds with today's Jalan Patimura, and Chinese straat (Chinese Street) with Jalan Alexander Jacob Patty. Breede straat (Broad Street) on the seaside is probably identical with Jalan Kemakmuran, whereas Prince straat (Prince Street) and Mardijkersstraat (Mardijkers' Street) corresponds with Jalan Sultan Hairun and Jalan Telukabesi, respectively. ${ }^{11}$

In the 1620s, attempts were made to register property rights to land and houses. However, because of the negligence of both the authorities and the inhabitants, it was not until the 1680 s that a reasonably adequate cadastral administration was established. ${ }^{12}$ What did these houses look like? Usually, the walls of the bigger houses were made of stone up to a height of $1.5 \mathrm{~m}$; above this level they were of wood. The roofs were thatched with palm leaves. The smaller houses, pedak, were entirely wooden structures. In the 1640s, to direct house building in a more or less orderly fashion, the VOC nominated a rooimeester, a kind of building inspector. Every potential builder was obliged to ask the inspector, who was always a Company employee, for permission and to let the inspector decide on building boundaries. The inspector also supervised the condition of the town's streets, which not only functioned as traffic lanes but also served as drains. In the rainy season in particular, tremendous quantities of water came down from the mountains to the sea. This water was supposed to find its way not only through the rivers but also through the small ditches along both sides of the streets. Each householder was responsible for the upkeep of the ditches in front of his or her dwelling. The ditches were always in danger of being blocked by animals, especially pigs, which ran free and fouled the streets, and humans, who deposited all sorts of garbage. The rooimeester had to see that the streets and the ditches were kept in good shape and that everyone carried the garbage to the places allotted for that purpose near the seashore. ${ }^{13}$

As the duties of the rooimeester gradually increased, he was assisted by wijkmeesters, overseers of city blocks, who were chosen from the ranks of the citizenry. The Company had

\footnotetext{
${ }^{10}$ Knaap, Memories, p. 7; Rumphius, "Ambonsche Historie," pt. 1: 51, 77; pt. 2: 119; J. Mooij, Geschiedenis der Protestantsche Kerk in Nederlandsch-Indië 1602-1636 (Weltevreden: Landsdrukkerij, 1923), p. 213; Fr. Valentijn, Oud en Nieuw Oost-Indiën, vol. 2 (Dordrecht: Van Braam, 1724), Beschrijvinge van Amboina lhereafter cited as Beschr.], pp. 130-33; VOC 1243: 1102.

11 Rumphius, "Ambonsche Historie," pt. 1: 53; Knaap, Memories, p. 11; Valentijn, Oost-Indiën, Beschr., pp. 125-26, 134.

12 Rumphius, "Ambonsche Historie," pt. 1: 53; Valentijn, Oost-Indiën, Ambonsche Zaaken [hereafter cited as Amb. Z.], p. 252; Knaap, Memories, p. 250.

13 Valentijn, Oost-Indiën, Beschr., pp. 126-27; Amb. Z., pp. 251-53.
} 
already divided the town into four blocks in 1666 . The four wijkmeesters had to see that the inhabitants disposed of their garbage in the proper places and that they kept six to twenty bamboo cylinders at hand, according to the size of their houses, each filled with five liters of water for mutual assistance in case of fire. Moreover, the rooimeester and the wijkmeesters also had to see that no one distilled arak, i.e., locally produced spirits, or coconut oil in a house that was considered too small for that purpose. Nevertheless, after the great fires of 1686 and 1687, when whole streets were reduced to ashes, Governor Robert Padtbrugge ordered that first, all houses must be built at least three meters apart and, second, that all roofs must be made with tiles. The fulfillment of the first obligation, in particular, caused great difficulty for those owners who had built their houses on relatively small pieces of land. ${ }^{14}$

Portuguese Kota Ambon had not possessed defensive works such as town walls and ditches. The Dutch at first left it that way. The Company was of the opinion that serious enemies would only approach Kota Ambon by sea. There the castle already provided protection. Enemies from the mountains were not expected. However, on two occasions, in 1616 and 1636, the Ambonese Christians from the hinterland rose up against the Company and threatened the city, although in the end no full-scale attacks followed. Nevertheless, in 1636, the threat resulted in the erection of a temporary wooden encirclement of the city. In 1665, when there were rumors of a Makassarese attack on Ambon, the city was again surrounded by such a temporary construction. Finally, in the $1680 \mathrm{~s}$, Governor Padtbrugge gave the city its moats and ditches, which were only realized by using large-scale compulsory labor from the Ambonese villagers. The complaints about these excessive labor duties were one of the reasons that Padtbrugge was summoned back to Batavia by the High Government in 1687. Within a few months of Padtbrugge's departure, Ambon was struck by heavy rains that left his moats and bulwarks in very bad condition. In June the following year, the rains struck again with the result that the works were irretrievably destroyed. After this failure, no effort was made again to fortify the city. ${ }^{15}$

\section{Governing the City}

In VOC times, a separate Kota Ambon government did not exist. The body that governed the province of Amboina, that is Ambon island and the surrounding archipelago, the Political Council, also made the major decisions concerning the town's administration. The council resided at the castle and, at the end of the seventeenth century, consisted of the governor, who was the head of the council, the opperkoopman (senior merchant), who was the head of the internal VOC administration, the captain, who was the leader of the garrison, the fiscaal (an attorney or judge), and the garrison bookkeeper. Whenever present in town, the rulers of the districts of Hitu and Saparua also attended the sessions of the council. The only institutions to which the Political Council was accountable were the High Government in Batavia and, still farther away, the "Heeren XVII" (the directors of the VOC) in the Netherlands. ${ }^{16}$

Of course, the Political Council firmly controlled that part of the town's population that was in the service of the VOC. The number of Company servants in the province of Amboina increased steadily from a few hundred at the beginning of the seventeenth century to

\footnotetext{
14 VOC 1309: 848r-849v; Valentijn, Oost-Indiën, Beschr., pp. 126-27; Amb. Z., p. 257; Knaap, Kruidnagelen, p. 195.

15 H. T. Colenbrander, ed., Daghregister gehouden int casteel Batavia 1636 (The Hague: Nijhoff, 1899), p. 230; Knaap, Kruidnagelen, pp. 22, 39, 45-47, 152; Knaap, Memories, pp. 250, 273; VOC 1260: res. 30-7-1666; 1437: 100r-101v; 1453: 62r.

16 Valentijn, Oost-Indiën, Beschr., pp. 277-78, 338; Knaap, Kruidnagelen, pp. 269-70.
} 
almost one thousand at the end of it. About 50 percent of them were concentrated in the castle and the town. The largest sectors in the VOC organization were the military and naval, but the most powerful was the commerce sector, which decided all matters concerning general policy and trade. Apart from the captain, all officials in the Political Council were recruited from this sector. Considering its duties, a more proper label for it would have been "civil service." The non-Company servant population of the town, usually called burgers, or colonists, were divided into three vertically organized sections: the European, Chinese, and indigenous burgerij (citizenry). Although each citizenry possessed leaders of its own, their autonomy was very limited. It was the Political Council, which after consultation with the most prominent members of the respective citizenries, nominated the leaders. These leaders possessed executive powers but lacked any decision-making authority. ${ }^{17}$

The phenomenon of the European citizenry, or Vrijburgerij (free citizenry), originated in about 1610. As soon as the Dutch took over from the Portuguese, a few Company servants began regular sexual intercourse with Asian women. As early as 1607, Adm. Cornelis Matelief allowed Dutch men to officially marry Ambonese and other Asian women. Because it was very difficult for a European married to an Asian woman to be repatriated, some employees left the service and tried to make a living in town. Moreover, leading Company circles in the Netherlands deemed it necessary to stimulate the growth of this category of settlers by sending colonists direct from Europe. The motive behind this initiative was that in times of danger the colonists could assist the VOC militarily, just as the casados were doing in the Portuguese towns. Consequently, in 1611, a contingent of twenty-five European families arrived in Ambon to found a colony. This attempt, however, was not very successful because, apart from difficulties in earning a decent living, the morals of the people concerned left much to be desired, at least according to the critical Governor-General Jan Pietersz. Coen. It is not surprising, therefore, that after this first attempt at direct Dutch immigration to Ambon nothing further is heard about the subject. Consequently, Company servants who left the VOC were the only source of new members for this group. Because the VOC was not only a secure employer but also an employer that was very often short of hands, the growth of the Vrijburger community was not very impressive. Moreover, because of the shortage of European females, its composition always was liable to "mestizofication." Around 1700, the European citizen group, including several mestizos, was only seventy males strong. ${ }^{18}$

The history of the Chinese citizenry started very soon after that of the European Vrijburgerij. It dates more or less from the same period as the foundation of Batavia in 1619. The immigration of Chinese to Ambon may be seen as an indirect result of the policy of the VOC to attract Chinese settlers to the colonial capital. Just before 1620, there was already word of an influx of Chinese migrants into Ambon, and around 1630, they numbered one hundred. ${ }^{19}$

After 1650, the prosperous and well-to-do Chinese community was confronted with a less favorable policy from the authorities. In the second half of the 1650s and the first half of the 1660 s, there were initiatives in government circles to forbid all Chinese involvement in the internal and external trade of the province of Amboina and to order them to concentrate

17 Valentijn, Oost-Indiën, Beschr., pp. 270,338; Knaap, Kruidnagelen, pp. $279-80$.

18 Rumphius, "Ambonsche Historie," pt. 1: 27; H. T. Colenbrander, Jan Pietersz. Coen. Bescheiden omtrent zijn bedrijf in Indië (The Hague: Nijhoff, 1934), 6: 40, 42, 49; Mooij, Geschiedenis, p. 49; Valentijn, Oost-Indiën, Beschr., p. 270.

19 Colenbrander, Coen, p. 271; Rumphius, "Ambonsche Historie," pt. 1: 83; L. Blussé, Strange Company. Chinese settlers, Mestizo Women and the Dutch in VOC Batavia, Verhandelingen van het Koninklijk Instituut voor Taal-, Land-en Volkenkunde 122 (Dordrecht: Foris, 1986), pp. 80-81. 
exclusively on agricultural and handicraft businesses. Those who were not willing to do so were faced with the choice of either leaving Ambon or becoming Christian. The reason for this rather hostile approach can be found in the VOC's fear that the Chinese, by way of their trading networks and credit facilities, would stimulate the smuggling of cloves, a trade that was the monopoly of the Company. The anti-Chinese policy also might have resulted from pressure from their politically more influential rivals, European citizen traders, or a general fear of the Chinese in these years because of the Chinese takeover of the VOC's positions in Taiwan in 1662. In time, because the Chinese were considered indispensable for the trade relations of the province, in particular for the import of rice, anti-Chinese sentiment disappeared. Now and then, however, anti-Chinese tendencies rose again. Nevertheless, the number of Chinese became quite substantial; by 1700 there were some two hundred men, the majority of them Buddhists. In the Chinese citizenry, a mestizofication tendency was visible as well. Because of the lack of Chinese women, many Chinese had to marry Indonesian women, usually former slaves of Makassarese or Balinese origin.20

The indigenous citizenry is sometimes equated with the nineteenth and early twentiethcentury Ambonese citizenry, that is, a citizenry that consisted of ethnic Ambonese. ${ }^{21}$ However, this grouping is a mistake because "indigenous" in Company times was a label used for Asians in general. In the seventeenth and most of the eighteenth century, the indigenous citizenry consisted of non-Ambonese, "foreign," Asians. In 1605, it included mainly orang merdeka, or Mardijkers, as the Dutch used to call them, who had been left behind by the Portuguese. During the entire seventeenth century, this group was reinforced by mestizos and/or migrants from other parts of Asia. In 1656, for instance, a considerable number of former Makassarese prisoners of war strengthened their ranks. The most regular and substantial growth, however, was contributed by the influx of freed slaves, usually of Makassarese, Butonese, Buginese, and Balinese origins. Around 1700, Mardijker-labeled men numbered some 230, whereas the number of men of South Sulawesi/Balinese origin approximated 210. According to their names, about 90 to 100 percent of these people must have been Christian. From an ethnological standpoint, the indigenous citizenry could have been the largest citizenry. At the end of the seventeenth century, however, this was not the case because of administrative reasons. ${ }^{22}$

As mentioned, each of the three citizenries had its own leadership, nominated by the Political Council from its most prominent members. The Chinese were the first to have such a leader, called the Chinese captain. In 1619, a Christian Chinese, Herman, became the first to hold this position. The first names of European and indigenous captains appear in the records of the 1630s. It is possible, however, that the first European and indigenous captains were nominated at a much earlier date. The European and indigenous citizenries counted in their ranks, besides a captain, a lieutenant, an ensign, and even sergeants and corporals. On the contrary, the Chinese had to make do with a captain only. This difference resulted from the fact that the European and indigenous citizenry each raised a militia company as a town guard. Instead of militia duties, every Chinese man had to pay one, later three-quarters, of a rixdollar per month to the VOC. According to the instructions for the citizen's militias, dating from 1688, every male citizen between the ages of sixteen and sixty years was liable to guard duty and had to bring his own weapon for that purpose. Only the captain, the lieu

${ }^{20}$ VOC 880: 500; 888: 599; 889: 659; Valentijn, Oost-Indiën, Beschr., pp. 259, 268, 270.

21 H. J. de Graaf, De geschiedenis van Ambon en de Zuid-Molukken (Franeker: Wever, 1977), p. 132.

22 Valentijn, Oost-Indiën, Beschr., pp. 269-70; Knaap, Kruidnagelen, p. 279; Knaap, Memories, p. 201. 
tenant, the ensign, and the six sergeants could bear weapons that were paid for by their company. Overall, one-third of a company was required to be armed with pikes and twothirds of the company with muskets. ${ }^{23}$

In 1647, the European militia was 41 strong and the indigenous, 74 . In 1656, the numbers were 58 and 73 , respectively. Twenty years later, in 1676, the relative strength of the European militia had dwindled. Although it had grown to 80 members, the indigenous militia had grown much faster, to 202. According to Valentijn, however, around 1700 both militias were 250 strong. This last figure is rather surprising because the number of ethnic European and mestizo men did not even total 100.24 What had happened? Because of demographic trends, the rather influential and well-to-do European citizen officers tended to become a class of "generals without soldiers," whereas their counterparts, the indigenous officers, because of the fast-expanding group of relatively poor followers, were almost drowning in soldiers. The Political Council, therefore, decided during the late 1680 s to enlarge the European citizenry with a number of people from the poorer sections of the indigenous citizenry. So, in the end, the European citizenry was not "white-washed" but "painted black." This change must be interpreted as a token of the privileged position of the elite of the European Vrijburger class in matters of political concern. Another sign of this was the fact that all the wijkmeesters nominated from the 1660 s onward were leading Dutch citizens. Of course, the European citizens owed this favored position to the fact that ethnically and culturally they were close to the decision-making Political Council.25

In the province of Amboina, justice was administered according to the legal status of the subjects. Thus, there was a Raad van Justitie (Council of Justice), that presided over affairs concerning Company servants, a Landraad for cases in which the Ambonese villagers were involved, and a Schepenbank (Bench of Aldermen), that served the interests of the citizens. Only the Council of Justice and the Bench of Aldermen will be dealt with here. The Council of Justice originated from the first decades of VOC rule, and its members were largely the same as those of the Political Council. The Bench of Aldermen was installed in 1628 and had as members four Company servants, four Ambonese village chiefs, and four prominent citizens. In 1663, however, the Bench of Aldermen was dissolved and henceforth the affairs of the citizens were dealt with by the Council of Justice, which for these special cases was temporarily enlarged to include one or two prominent citizens. Because of this dual role as well as the ongoing growth of the urban population, the number of cases brought before the Council of Justice greatly increased. To lighten the load of its members, a special Council of Small Affairs that dealt with minor civil cases, was established around 1666 . The composition of this council closely resembled that of the previous Bench of Aldermen. ${ }^{26}$

Although the role of the leading citizens in the government of the town did not show any substantial expansion, no serious opposition against the rule of the Political Council ever emerged from the ranks of the citizenries. Apart from the fact that the VOC employed approximately 40 percent of the male nonslave town population and that it could count on a strong military position in the castle vis-à-vis the town, the vertical division of the population along the lines of separate citizenries was probably responsible for the absence of oppo-

\footnotetext{
23 Valentijn, Oost-Indiën, Beschr. pp. 268, 341; P. A. Tiele, ed., Bouwstoffen voor de geschiedenis der Nederlanders in den Maleischen archipel, (The Hague: Nijhoff, 1886), 1: 253; Rumphius, "Ambonsche Historie," pt. 1: p. 132; VOC 1453: $48 \mathrm{v}$.

24 Knaap, Memories, pp. 176, 201; Valentijn, Oost-Indiën, Beschr., p. 347; VOC 1317:359v.

25 VOC 1309: 849v res.; 7953, 1436, 1451, 1461, 1481: zielsbeschr.

${ }^{26}$ Knaap, Memories, pp. 94, 211, 422; Valentijn, Oost-Indiën, Beschr., pp. 339-40; Knaap, Kruidnagelen, p. 39.
} 
sition. A coalition of all three citizenries was very unlikely. In particular, the European and the Chinese citizenries were at times in fierce economic competition. The leaders of the European citizens must have been aware that although the VOC limited their freedom, without the protection of the VOC they would have been lost. The most ardent opponents of the Political Council in Kota Ambon were, therefore, found in quite another corner of society, notably in the ranks of the Company itself, the Calvinist ministers.

As in the Netherlands, the affairs of the local Protestant church were taken care of by a Kerkeraad (Church Council), which in Ambon was founded in 1625. Besides the ministers themselves, this council usually consisted of a few laymen, such as one Company servant, at least one European citizen, and two Ambonese village chiefs. The ministers, varying in number from two to five, always dominated the scene. Throughout the entire seventeenth century, as in other VOC settlements, there appeared to be a tradition of conflict between the ministers and the Political Council. These conflicts were partly personal and partly a matter of principle. The background of the conflicts based on principle can be found in the theocratic tendencies within the seventeenth-century Calvinist church in the Netherlands. In the opinion of many a church minister, the church should not be subject to the intervention of political authorities. The ministers who went to Asia, however, were on the Company's payroll, and as such, they were Company servants who had to obey the orders of the Political Council. So one should not be surprised that clashes took place at regular intervals between ministers and governors and that the authorities responded to this by curbing the autonomy of the Church Council as much as possible. The first step in this process was the introduction of a delegate in the meetings of the Church Council, whose duty it was to report on the proceedings of the Church Council to the Political Council. After fierce opposition, the ministers were forced to accept this intrusion in $1631 .{ }^{27}$

The next step that took away part of the ministers' authority took place around 1660 . Before that time, every Christian who wished to marry had to ask advice and permission from a minister. This task was then given to a special Council for Marriage Affairs, which shortly afterward merged with the Council for Small Affairs. The VOC, the European citizenry, and the Ambonese village chiefs had their own representatives in this new council. Ministers, however, were excluded. At the beginning of the century, the Church Council also administered the income and expenditure of the poor. In 1690, however, a special Board of Deacons was created to which no ministers were nominated. Thus by the end of the seventeenth century, the powerbase of the ministers had become very narrow. ${ }^{28}$

The existence of institutions to take care of the poor suggests another aspect of urban life that should not be overlooked. Given the migrant nature of Kota Ambon society, the authorities were more or less obliged to provide for the care of orphans and inheritances. As far as the Christian majority was concerned, these matters were treated by the Board of Trustees, already existing in the 1630s and consisting of two Company servants and three citizens, as well as the VOC itself and/or the previously mentioned judicial organizations. All matters concerning the inheritance of non-Christians, mainly Chinese, were dealt with by the Council of Executors of Chinese Estates, founded in 1647. This council was presided over by the administrator of the Company's cloth shop and had as members the captain of the indigenous citizenry, the captain of the Chinese citizenry, and other prominent Chinese. ${ }^{29}$

\footnotetext{
${ }^{27}$ Mooij, Geschiedenis, pp. 206, 208, 218.

28 VOC 1497: 64r-66v; Knaap, Memories, pp. 94, 176.

29 Valentijn, Oost-Indiën, Beschr., p. 340; Knaap, Memories, pp. 94, 176.
} 


\section{Economic Structure}

Did Kota Ambon dominate its surrounding countryside? From a political point of view, it certainly did. The government of the province of Amboina resided in town. But did it dominate the countryside economically as well? Again this question can be answered affirmatively. The city was the channel through which all imports and exports took place, at least after the VOC had subdued the final resistance of the Ambonese against its rule in the 1650s. All important decisions concerning Ambon's only substantial export item, cloves, were taken by the VOC, which had already established a trade monopoly in this product in the 1640s. The domination, however, was a VOC affair; the citizen community did not take part in it to any substantial degree. The VOC had forbidden the citizens to cultivate or to trade in cloves. Thus, the only opportunities the citizens had to participate in the internal economy of the province were in retail trade, mainly of imported items such as textiles and Chinese earthenware. Their chances in this field were still limited because the Ambonese economy was very subsistence oriented. There proved to be little scope for penetration into this rather closed economy. The citizens did not participate much in the external trade relations of Ambon either, for the Company's ships carried the entire clove export. The citizens' outward-bound trading vessels left Ambon almost empty, which meant that the profits on foreign trade had to be made on the homeward-bound voyage. Moreover, the VOC, always afraid that somebody might threaten its clove monopoly, set limitations on the routes and destinations of private shipping. ${ }^{30}$

An examination of the city's internal economic structure reveals, that in 1694 more than 40 percent of the total adult male population, 540 out of approximately 1250 , was in the service of the VOC, a very substantial number indeed. Numbering 318, the military sector was the strongest inside VOC ranks, whereas the naval, the craftsmen, and the commerce sectors had 83, 60, and 45 members respectively. Kota Ambon was not only a center of government but also a garrison town. Many a Company servant, in particular those in the military group, had to live on a small salary, which was paid only occasionally. The larger part of the salary was kept by the Company, to be paid only when the employee left the service. Exceptions to this rule were possible, for instance, when a person married in Asia and had to spend the salary on the upkeep of his household. In the entire province of Amboina in 1694, the total annual sum of salaries for all Company servants should have been some $f 200,000$. Only f 120,000, 60 percent, was actually paid; the rest remained on Company books. ${ }^{31}$

To give some examples of payments to Company servants: a soldier had a monthly salary of $f$, a sergeant and an assistent (clerk) $\mathrm{f} 20$, a minister almost $\mathrm{f} 100$, and the governor $f 200$. In addition, every employee received kostgeld (boarding money): the soldier $f 4$ per month, the sergeant and the clerk almost $f 10$, and the minister approximately $f 30$. The governor received almost $f 75$ plus an extra sum of $f 60$ to cover the cost of entertaining his official guests. The servants could also count on provisions from the Company's stores. The lower ranks had to make do with one man's ration of rice. The higher a person's rank, however, the more he received. The governor, for instance, could count on considerable deliveries of beer, butter, vinegar, Persian wine, and so forth. His annual rice ration amounted to $3,000 \mathrm{~kg}$, whereas his ration of European wines was $7001 .^{32}$

\footnotetext{
${ }^{30}$ Knaap, Kruidnagelen, pp. 22-23, 218-22.

31 VOC 1551: zielsbeschr.; 1573: 508r-519v.

32 Valentijn, Oost-Indiën, Beschr., p. 284; F. W. Stapel, ed., Pieter van Dam: Beschrijvinge van de Oost-Indische Compagnie, Rijks Geschiedkundige Publicatiën 87 (The Hague: Nijhoff, 1943), 3: 230, 265-66, 286; C. R. Boxer, The Dutch Seaborne Empire 1600-1800 (London: Hutchinson, 1977), pp. 300-1.
} 
The highest officials, such as the governor, the senior merchant, and the captain, belonged to the richest class in town. Besides the above-mentioned income, the governor had exclusive rights to fisheries at particular places in the Bay of Ambon and to the overwichten, that is, the extra weight that occurred on cloves exported to Batavia. This extra weight was the result of the cloves becoming more hydrated in the period between their delivery by the villagers and the shipment from Ambon. The average value of the extra weight amounted to $f 4,000$ to $f 5,000$ annually. Moreover, the governor received a small percentage of the Company's turnover of rice and Indian textiles. The senior merchant also had extra income from the clove trade. He and his assistants were supposed to charge the Ambonese villagers $0.5 \mathrm{lb}$ of tare on the delivery of each bag of cloves. Because the bags were never as heavy as $0.5 \mathrm{lb}$, the senior merchant could expropriate the difference between the total theoretical and the total real delivery of cloves. The senior merchant was also involved in buying arak from the crews of incoming Company vessels, which he then sold to urban dwellers. The sale of arak seems to have been a most important business for the captain as well. He appeared to be one of the principal suppliers of the garrison. The governor, senior merchant, and captain were also moneylenders to Ambonese clove cultivators, private VOC employees, and citizens, as well as to the VOC itself. They could always also earn something from bribery to promote lower-ranking employees and in lawsuits. Finally, there was the possibility of squeezing the Ambonese by not turning over the whole payment for the delivery of cloves or by having them work as compulsory laborers a few days extra for the governor's or any other high official's private purpose. ${ }^{33}$

These practices were partly legal, partly illegal. The line between the two was not always easy to draw. Occasionally, the High Government in Batavia tried to cope with the most serious abuses by investigating the conduct of a particular person, such as Governor Jacob Cops in 1672. He was accused of having used slaves, craftsmen, compulsory laborers, and building materials from the Company to build at least twenty-four houses for himself. He also appeared to be an "invisible" partner in the farming-out of the arak monopoly and of the monopoly for sago extraction in the Company's forests. In addition, he also partly owned four citizens' vessels. When all this came to light, Cops replied that he had lawfully paid for everything needed for the building of his houses, but, alas, had forgotten exactly how much. As regards his participation in all kinds of farm contracts and in private ships, he stated that this was not deemed explicitly illegal and pointed to the behavior of Cornelis Speelman, the conqueror of Makassar. ${ }^{34}$ Cops was recalled to Batavia, which, of course, does not mean that his successors did not act in the same way. It is likely that they were not as extensively involved as Cops and/or more successfully concealed their dealings from Batavia.

The "official" economic activities of the VOC, reveal a large turnover of cloves that were collected from the villagers in the province under monopoly stipulations and exported to Batavia by way of Kota Ambon. This activity-apart from the mentioned occasional legal and illegal opportunities for individual Company employees-did not, however, render much income to the VOC branch of Amboina. At the end of each financial year, the entry of cloves vanished from the books: within the span of one year, the entire harvest was collected and turned over to Batavia, physically as well as administratively. The VOC Amboina branch had to earn surpluses on less important trades, which amounted to only a fraction of its total expenditure. In 1694-1695 for instance, the VOC government at Victoria spent

33 Valentijn, Oost-Indiën, Beschr., pp. 275, 278, 287-88, 299-300; Knaap, Kruidnagelen, pp. 243-45.

34 VOC 1286: 572v-578r; 1297: 482v-486r. 
f 193,000 against a credit balance of $f 70,000$. This figure of $f 70,000$ was realized in two ways: commercially and fiscally. Commercially, every now and again the VOC sold rice and manufactured articles, such as nails, sails, and so forth, to private persons. By far the most profitable trade item, which rendered some $f 28,000$ annually, was the sale of Indian textiles in the Company's cloth shop in front of the castle. Just over one-half of the returns were realized fiscally. Here one notices a subdivision between income earned directly through the VOC servants themselves and indirectly through tax farmers. ${ }^{35}$

The directly realized income from fiscal sources came from such things as small fees for endorsing legal documents and issuing safe-conducts for private shipping, the collection of import and export duties, licenses for building a house or making a seru (semi-permanent construction for fishing) in Kota Ambon's roadstead, and collecting a tax from the peddlers who used the marketplace. ${ }^{36}$ The indirectly realized income was generally derived from farming out taxes. This phenomenon was mainly connected to the urban economy and dated back from about 1620 . After a few alterations, this institution reached its ultimate shape in the second half of the century. Around 1694, the total sum of tax farming amounted to approximately $\mathrm{f} 34,000$ annually. By far the most important form of tax farming was that of arak and sageru, which rendered $f 24,000$. Sageru was the locally produced palmwine, the sale of which was liable to a small duty. Arak was a spirit distilled from sageru and was very popular among the urban populace. The tax farmer and his partners had the exclusive right to burn and deliver arak to private persons and pubs. He also had the right to tax imported arak. This quite important business was usually in the hands of a Chinese, but the control over it was often challenged by the leaders of the European citizenry. To this end, they appealed to the VOC government. Their attempts, however, met only with temporary success as in the end the Chinese always won the day. ${ }^{37}$

In the private sector of the urban economy, as in almost every preindustrial city, a large segment of the population still was agriculturally oriented. In all sections of the citizenry one encounters agricultural occupations, but the Chinese and Makassarese, in particular, specialized in growing food crops, albeit on a small scale. Rich European citizens owned some cows to produce milk and butter for the market. In the European-mestizo and the Mardijker-Makassarese communities, one also comes across some hunters, fishermen, palm wine tappers, and, finally, firewood cutters. In all ethnic groups, Chinese, European-mestizo as well as Mardijker-Makassarese, one notices persons, who with the assistance of slaves, were working as carpenters, blacksmiths, masons, tailors, or shoemakers. Then some people, in particular in the European-mestizo group, ran pubs. In 1662, there were thirty such publicans or inn keepers. Moreover, there were people, men as well as women, probably mainly from the Chinese and the Mardijker-Makassarese group, who were regular market traders. In 1675, they numbered approximately ninety. The Chinese were the shopkeepers for the Ambonese and traveled around the countryside. Most of these small traders got their merchandise from bigger merchants who were usually Chinese as well. At the end of the seventeenth century, there were approximately ten such bigger traders. They dominated the distribution of Indian textiles from the Company's cloth shop to the consumers. In

35 VOC 1573: 508r-519v; Knaap, Kruidnagelen, pp. 220-21, 223-24.

36 Knaap, Kruidnagelen, pp. 177, 211-12, 216, 218, 221.

37 VOC 1535: 28v, 104v; 1556: 71v; W. Ph. Coolhaas, ed., Jan Pietersz Coen. Bescheiden omtrent zijn bedrijf in Indië (The Hague: Nijhoff, 1953), 7b:969-70;Valentijn, Oost-Indiën, Beschr., pp. 258, 341; Knaap, Kruidnagelen, pp. 18788. 
this respect, the leading European citizens once again complained bitterly about this domination, but to no avail. 38

The bigger Chinese merchants were powerful businessmen, as were the distillers of arak, who usually employed at least twelve slaves to keep this business going. It is difficult to estimate the number of these distilleries. Evidence from the 1670s suggests that the number varied between two and seven and that the Chinese dominated this trade. The Chinese and a few European citizens also excelled in sawmilling; every mill usually employed some fifteen to twenty slaves. How many businessmen were engaged in this profession is not known. Another business that flourished, particularly at the end of the seventeenth century because of the Company's building activities was the production of tiles and bricks. An average tile- and brickworks operated with approximately twenty slaves and three to four buffaloes and earned some f 3,000 to $f, 000$ annually. Chinese owned six or seven of these works and European citizens three to four. ${ }^{39}$

As stated, Kota Ambon was the province's external harbor. It also was as a center for local trade, but I do not have figures about the extent of this phenomenon. The trade was in locally produced foodstuffs, mainly sago and fish products, against textiles, small iron tools, pottery, and salt. For external trade, it is noteworthy that in the last half of the seventeenth century ten to fifteen VOC ships and thirty to fifty privately owned vessels called annually. The Company ships served as communication links with Batavia and the neighboring provinces of Ternate, Banda, and Makassar and were mainly used for carrying troops, ammunition, and all kinds of equipment. They also carried imported Indian textiles, Javanese rice, and European hard currency. The currency paid for the only important export cargo, cloves, of which approximately $600,000 \mathrm{lbs}$ were shipped annually. The privately owned vessels must have departed with almost empty holds as there was, apart from the VOC cloves monopoly, no export item of any value. They returned with loads of Sulawesiproduced textiles, rice from Java and Makassar, Chinese and Tonkinese pottery that was taken in at Batavia, and, finally, Balinese, Makassarese, Buginese, and Butonnese slaves bought in Batavia or Makassar. The import of slaves, however, was gradually limited by the government because it feared those of certain origin, principally Balinese and Makassarese, which were deemed to be "dangerous." Whether this limitative policy had any real effect is hard to say, however. ${ }^{40}$

The bigger ships of the VOC that called at Kota Ambon's roadstead did not have this town as their homeport. The Amboina branch of the VOC possessed only a few smaller vessels for local transport and/or patrol duties. In 1694, they numbered three. One can only guess at the number of privately owned ships that were used for internal trade or journeys to neighboring provinces on the basis of information from the $1680 \mathrm{~s}$. The number probably must have been twenty-three, all of which could carry no more than 30 last (one last equaled $2,000 \mathrm{~kg}$ ). The number of vessels with a capacity of over 30 last sailing to Makassar or distant Java and Batavia has been calculated at twenty-two-one more than in the year 16791680. In that year, seven out of twenty-one vessels belonged to Europeans, ten to Chinese, and four to members of the indigenous citizenry. Again, the Chinese played a more important role than other groups. These larger ships were, according to Valentijn, usually manned by approximately fifteen sailors each, which means that the number of sailors in Kota Am-

38 VOC 1240: 728; Valentijn, Oost-Indiën, Beschr., pp. 257-58, 269, 349-50; Knaap, Kruidnagelen, pp. $211,224$.

39 VOC 1271: 32r; 1309: 824v res.; 1334: 74r res.; Valentijn, Oost-Indiën, Beschr., p. 257; Knaap, Memories, pp. 251, 281.

40 Knaap, Kruidnagelen, 134-35, 212, 219-22. 
bon must have been at least three hundred. Many of them were recruited from the poorer segments of the indigenous citizenry at $f 9$ per month. ${ }^{41}$

\section{Demography}

According to population figures, Kota Ambon witnessed a steady growth throughout the seventeenth century. When the Dutch took over from the Portuguese in 1605, the population could be counted by the hundred. Just after 1610, there were already more than 1,500 inhabitants. In 1673, the population was 4,089 and in $1694,5,487$. In 1673, the strength of the group of VOC servants and their families, the European, the Chinese, and the indigenous citizenry was $1,198,748,967$, and 1,176 , respectively. In 1694 , these numbers were 1,500 , $1,868,1,109$, and 1,010. The turnover of many Asians from the indigenous to the European citizenry at the end of the 1680 s has already been discussed..$^{42}$

From approximately 1670 onward, the VOC held annual censuses for the entire province of Amboina. Those from the years 1671 to 1695 have been preserved and have been analyzed critically elsewhere, as far as the Ambonese rural population is concerned.43 On the basis of these censuses, zielsbeschrijuingen (descriptions of souls), it is also possible to analyze the composition of the urban population. One of the most striking facts derived from this analysis is that the number of slaves always exceeded one-half of the total population, usually between 50 and 60 percent. For the adult population (because children were not listed according to sex), the unbalanced sex-ratio is striking: only 40 percent were women-the result of the high proportion of unmarried Company employees and the unequal sex-ratio among slaves, which will be discussed later. ${ }^{44}$

On the basis of the censuses one can also estimate the ethnic composition of the urban population. For the nonslave population, almost 50 percent was of Southeast Asian, mainly Malay-Indonesian origin (Ambonese, Mardijker, Makassarese, etc.), followed by 25 percent of European and 15 percent of Chinese origin. Southeast Asians were found in the indigenous and/or European citizenry; the majority of the European and Chinese inhabitants were in the VOC group and the Chinese citizenry, respectively. When one takes the slave population into account, a more complete picture of the situation arises. Because over 90 percent of the slaves had a Southeast Asian ethnic background, it is not astonishing to find that 75 percent of the total population was of Southeast Asian origin. Less than 5 percent of the Southeast Asians were of Ambonese origin, which leads to the conclusion that Kota Ambon was clearly a Southeast Asian migrant city. By "immigrants" are meant non-Ambonese who had been resident in the town for one, two, or sometimes even three generations. Compared to the 70 percent Southeast Asian immigrant majority, the European and Chinese segments were only small minorities. ${ }^{45}$

The census of 1694 has been analyzed in detail to obtain extra information about demographic patterns and behavior. ${ }^{46}$ This analysis, however, focuses on what will be called the "settled" population. "Settled" is defined here as "having or living in a household and/or family structure."

41 VOC 914: 1390-1; 1356: Dagregister Victoria; 1551: zielsbeschr.; Valentijn, Oost-Indiën, Beschr., p. 348).

42 Knaap, Memories, p. 11; VOC 1293: zielsbeschr.; 1551: zielsbeschr.

43 Knaap, Kruidnagelen, pp. 99-137, 279-82.

44 VOC 1293, 1385, 1551: zielsbeschr.

$45 \mathrm{Ibid}$.

46 VOC 1551: zielsbeschr. 
Table 1. Division of the Population According to the Degree of Settlement (1694)

\begin{tabular}{lrcccc}
\hline \hline & $\begin{array}{r}\text { VOC } \\
\text { Group }\end{array}$ & $\begin{array}{c}\text { European } \\
\text { Citizenry }\end{array}$ & $\begin{array}{c}\text { Chinese } \\
\text { Citizenry }\end{array}$ & $\begin{array}{c}\text { Indigenous } \\
\text { Citizenry }\end{array}$ & $\begin{array}{c}\text { Total } \\
\text { City }\end{array}$ \\
\hline Not settled & 558 & - & - & - & 558 \\
Settlement uncertain & 65 & 38 & 21 & 42 & 166 \\
Settled population & 877 & 1,830 & 1,088 & 968 & 4,763 \\
Total population & 1,500 & 1,868 & 1,109 & 1,010 & 5,487 \\
\hline
\end{tabular}

The 558 nonsettled persons are found entirely in the VOC group. It consists of 409 VOC servants and 149 other persons. The category of "other persons" contains, for instance, the 23 poor living at the expense of the Board of Deacons and the 101 persons in jail. The nonsettled VOC servants group includes all anonymous employees, who were only referred to in total numbers; 75 were ordinary sailors, and 234 were common soldiers. These anonymous employees must have lived in the barracks inside Victoria castle. The settled and settlement uncertain categories contain persons whose names are individually written in the census. The difference between certain and uncertain settlement has been taken to be whether the person in question possesses a male or female partner and/or children or slaves, or, is listed without any partner, child, or slave. When this criterion is applied, the conclusion can be drawn that many male persons have to be considered as uncertain settlers. An exception in the application of this criterion is made, however, for the few individually listed female persons without relatives or slaves. Usually these were labeled as "widow" or "free woman," which can be interpreted as an indication that these women had separate households that justified their inclusion in the category of definite settlers.

According to this criterion, it is easy to establish that only 12.5 to 24.5 percent of a total 542 Company servants residing in town were living in a household and/or family structure. Of Company personnel living in the outposts of the Amboina province, 18 percent, more or less the same proportion, were accustomed to family life. Of the settled Company servants living in town, it is not surprising to see that 78 percent were born in Europe. For the small section of settled ethnic European citizens, this percentage was even higher: 86 percent. Thirty-one percent of the Company servants and 42 percent of the European citizens originated from Europe outside the Netherlands.

Fifty and 77 percent, respectively, of the male Mardijkers in the European and indigenous citizenries were born in the Amboina province. This leads to the conclusion that the class of Mardijkers, ethnically non-Ambonese, in the second part of the seventeenth century, must probably be considered as a group of second- or third-generation freed slaves. In contrast, the group of Makassarese and related peoples, by which all Sulawesi and Nusa Tenggara ethnicities are meant, was usually not Ambonia born. Consequently, this category should be labeled as comprising mostly first-generation freed slaves. The southern part of the island of Sulawesi, including Buton, appeared to be the birthplace for 60 and 52 percent of these people in the European and indigenous citizenries, respectively. In both citizenries, 39 and 36 percent of the Makassarese and related peoples were born in Nusa Tenggara, which means that their ethnicity usually must have been Balinese, Timorese, or Bimanese. Unfortunately, in all cases of Chinese males in the Chinese citizenry the place of birth is not 
given. One can only guess that they must have been born either in China or in another area of Southeast Asia where migrant Chinese were living.

It is also possible to say something about the place of birth of female heads of households because when a household did not have a male head the name and place of birth of the female head was listed instead. Most of these women were widows. Fifty-five percent of the European citizenry originated from Sulawesi and Nusa Tenggara; for the Chinese and indigenous citizenries these numbers amounted to 54 and 56 percent, respectively, which indicates that the recruitment of marriage partners for male citizens was to a large extent freeing their favorite slave women.

Table 2. Composition of Households of the Settled Population (1694)

\begin{tabular}{lccccc}
\hline \hline & $\begin{array}{c}\text { VOC } \\
\text { Group }\end{array}$ & $\begin{array}{c}\text { European } \\
\text { Citizenry }\end{array}$ & $\begin{array}{c}\text { Chinese } \\
\text { Citizenry }\end{array}$ & $\begin{array}{c}\text { Indigenous } \\
\text { Citizenry }\end{array}$ & $\begin{array}{c}\text { Total } \\
\text { City }\end{array}$ \\
\hline Number of households & 89 & 257 & 130 & 197 & 673 \\
With male head & 68 & 193 & 91 & 149 & 501 \\
With female head & 21 & 64 & 39 & 48 & 172 \\
Average number of members & 9.85 & 7.12 & 8.37 & 4.91 & 7.08 \\
Average number of children & 1.03 & 0.91 & 1.25 & 0.88 & 0.99 \\
Average number of slaves & 6.55 & 4.34 & 5.53 & 2.29 & 4.26 \\
\hline
\end{tabular}

Most striking is the relative smallness of the average household in the indigenous citizenry, which resulted from the fact that such a household was not able to compete with households in the other groups as far as slave ownership was concerned. In the indigenous citizenry, the average number of slaves did not even exceed 50 percent of its total membership. In all groups, there is the same low number of children. Obviously, this migrant city could not have been able to maintain its numbers by natural reproduction.

Table 3. Proportionate (percentage) Distribution of Ethnicity of Heads of Households (1694)

\begin{tabular}{lcc}
\hline \hline & Male & Female \\
\hline European & 16.77 & 2.33 \\
Mestizo & 6.59 & 7.56 \\
Chinese & 19.56 & 11.05 \\
Mardijker & 25.55 & 27.32 \\
Makassarese, etc. & 29.54 & 49.42 \\
Ambonese & 2.00 & 2.33 \\
Total & 100 & 100 \\
\hline
\end{tabular}


The percentages for the males are not surprising in view of what was said previously. Suffice to say, that the European males could be found first in the VOC group and second in the European citizenry; the mestizos mostly in the European citizenry; and the Chinese mostly in the Chinese citizenry. The Mardijkers appeared first in the indigenous citizenry and second in the European citizenry. In the Makassarese and related peoples group, it was the other way around: they were most concentrated in the European citizenry and after that in the indigenous citizenry. Among the female heads of households, the number of the Makassarese group (i.e., the relatively recently freed slaves) was relatively large. Special notice should be taken of the female heads of households in the Chinese citizenry. More than one-half of them appeared to be of Makassarese group origin and less than one-half were pure Chinese. This should be a warning when one interprets the marriage pattern of the male Chinese citizenry where it seems that most of the wives of the Chinese were of pure Chinese origin. Quite a large number of these women, however, must have been former slaves, that is, South Sulawesi or Balinese women. ${ }^{47}$

Table 4. Proportionate (percentage) Distribution of Marriage Patterns of Male Heads of Households (1694)

\begin{tabular}{lccccc}
\hline \hline & $\begin{array}{c}\text { European } \\
\text { Male }\end{array}$ & $\begin{array}{c}\text { Mestizo } \\
\text { Male }\end{array}$ & $\begin{array}{c}\text { Chinese } \\
\text { Male }\end{array}$ & $\begin{array}{c}\text { Mardijker } \\
\text { Male }\end{array}$ & $\begin{array}{c}\text { Makassarese etc. } \\
\text { Male }\end{array}$ \\
\hline Not married & 13.10 & 35.48 & 20.41 & 12.50 & 4.73 \\
European wife & 29.76 & - & - & - & - \\
Mestizo wife & 25.00 & 32.26 & - & 0.78 & - \\
Chinese wife & 1.19 & 3.23 & 66.33 & 0.78 & - \\
Mardijker wife & 17.86 & 19.35 & 4.08 & 73.44 & 17.57 \\
Makassarese wife & 7.14 & 6.45 & - & 2.34 & - \\
Ambonese wife & 5.95 & 6.45 & - & 2.34 & - \\
Total & 100 & 100 & 100 & 100 & 100 \\
\hline
\end{tabular}

Obviously, it was almost impossible for a non-European to marry a European wife. European men preferred to marry European women, although mestizo partners were popular as well. Mestizo men were in a difficult situation because many mestizo women married Europeans. Apparently, a quite large proportion of them preferred not to (re)marry rather than to choose a partner from the Southeast Asian ethnic groups. As noted previously, the percentage of Chinese married to Chinese women is too high in this table; quite a lot of these so-called Chinese women were of the Makassarese group. Finally, the Mardijker and Makassarese preferred marrying women from their own ethnicity. They must have had no other choice.

\footnotetext{
47 Valentijn, Oost-Indiën, Beschr., p. 259.
} 
Table 5. Average Number of Children and Slaves According to Marriage Groups (1694)

\begin{tabular}{lccr}
\hline \hline & \multicolumn{3}{c}{ Number of } \\
\cline { 2 - 4 } & Unions & Children & Slaves \\
\hline European-European & 25 & 0.92 & 20.64 \\
European-mestizo & 21 & 1.33 & 5.86 \\
European-Mardijker & 15 & 1.40 & 2.93 \\
Mestizo-mestizo & 10 & 2.90 & 23.80 \\
Chinese-“Chinese” & 65 & 1.55 & 6.95 \\
Mardijker-Mardijker & 94 & 1.26 & 1.26 \\
Makassarese-Makassarese & 115 & 0.80 & 2.25 \\
\hline
\end{tabular}

As concerns the number of children, the small group of mestizo-mestizo unions with an average of 2.9 children did quite well. The lowest number of children was realized by the relatively large group of Makassarese-Makassarese: only 0.8 child per union. This fact is not difficult to explain because it is more or less in line with the situation in the slave population from which this first generation of freedmen originated. Because these couples must have been fairly old when manumitted, it is very likely that they would have been unable to have a large number of children. In unions with European men, the average number of children increased according to the degree of "Asianness" of their wives. In relation to the number of slaves they held an opposite trend can be seen, however: the more Asian the wife, the fewer slaves they possessed. The high average of slaves in the European-European union, usually the top-ranking VOC employees and their spouses, is, nevertheless, exceeded by that of the mestizo-mestizo union. However, the well-to-do mestizo lineages dealt with here were already long established in Indonesia and were usually found in leading citizen circles.

As stated, the slaves were the largest group in Kota Ambon. In 1694, they numbered $2,870,52.3$ percent of the total population. These slaves were almost entirely recruited from Southeast Asian ethnicities, although one may assume that in the first half of the century, when the VOC was not yet fully established in the Southeast Asian slave-trading networks, the number of Indian slaves must still have been quite high. Scarcely any of the Southeast Asian slaves were from Ambon itself. Most of them originated from South Sulawesi and Nusa Tenggara. The Makassarese-Buginese and Balinese ethnicities proved the most popular with slave owners because of their economic skills. ${ }^{48}$

The occupations of the slaves were varied. Slaves tilled the land and slaves fished. Slaves served their masters in their homes: they cleaned the house, cooked the meals, went to the market, carried firewood home, and accompanied their masters or mistresses when they went out. Slaves also were skilled craftsmen. Some of them worked in the arak distilleries, tile and brickworks, or sawmills, whereas others, particularly those owned by the VOC elite, were hired by the VOC when it was short of hands. The most trusted slaves were sent by their masters as traders on local sailing voyages. Finally, Makassarese and Balinese women were often used as concubines, particularly by the Chinese. Sometimes these liaisons were sanctioned when a concubine was promoted to official wife of the master by marriage. The

${ }^{48}$ Knaap, Kruidnagelen, pp. 128-33. 
last few examples of the use of slaves suggest that relations between masters and slaves were quite good. Quite often, however, relations were strained. Throughout the century one finds many references to fugitive slaves, who sometimes became dangerous, robbing travelers in remote parts of the islands. That relations were strained is also apparent from the slave legislation of the VOC. On the one hand, the government tried to prevent excesses in the treatment of slaves by their owners, but on the other hand, it was draconian in its measures against fugitives and/or slaves who physically opposed their masters. ${ }^{49}$

Although 52.3 percent of the total population of the town were slaves, when one excludes the nonsettled and uncertain settled free population, the proportion of slaves appeared to be 60.3 percent. They were more or less equally distributed over the four categories of population with the exception of the indigenous citizenry, which, with only 46.7 percent slaves, can be considered the poorest group. From the 2,870 slaves, 51.6 percent were adult males; 33.5 , adult females; and 14.9 , children. The proportion of adult males to adult females was 1:0.65, whereas that of adult females to children was 1:0.45. From these figures, one may assume that slave owners highly preferred male slaves, probably because they were supposed to be more useful for heavy, productive work. The small number of children makes it clear that it was continually necessary to import slaves to keep their number at a satisfactory level. The policy of the VOC to prohibit the import of unreliable slaves from Bali and South Sulawesi in 1666, 1683, and 1688, respectively must, therefore, have been a considerable threat to the economy of the urban population. Population statistics of a later date, such as those of 1694 or 1708 , still show such high numbers of slaves that it seems very unlikely that these prohibitions were effectively enforced. ${ }^{50}$

Table 6. Distribution of Slave Ownership (1694)

\begin{tabular}{lccccc}
\hline \hline & $\begin{array}{c}\text { VOC } \\
\text { Group }\end{array}$ & $\begin{array}{c}\text { European } \\
\text { Citizenry }\end{array}$ & $\begin{array}{c}\text { Chinese } \\
\text { Citizenry }\end{array}$ & $\begin{array}{c}\text { Indigenous } \\
\text { Citizenry }\end{array}$ & $\begin{array}{c}\text { Total } \\
\text { City }\end{array}$ \\
\hline Number of slaves & 583 & 1,116 & 719 & 452 & 2,870 \\
$\begin{array}{l}\text { Number of households } \\
\begin{array}{l}\text { Households without slaves } \\
\text { (Percentage) }\end{array}\end{array}$ & 89 & 257 & 130 & 197 & 673 \\
$\begin{array}{l}\text { Households with 1 or 2 slaves } \\
\text { (Percentage) }\end{array}$ & 24.72 & 40.08 & 25.38 & 41.62 & 35.66 \\
$\begin{array}{l}\text { Households with } 3 \text { to 10 slaves } \\
\text { (Percentage) }\end{array}$ & 33.71 & 22.18 & 31.54 & 21.32 & 25.26 \\
$\begin{array}{l}\text { Households with 11 or more slaves } \\
\text { (Percentage) }\end{array}$ & 19.10 & 8.56 & 16.15 & 4.06 & 10.10 \\
\hline
\end{tabular}

Again the data illustrate that the indigenous citizenry was the poorest category among the settled population. The European citizenry was the next poorest, as evidenced by 40 percent of households without slaves. Most of these, however, were found among its Makassarese and Mardijker sections, notably the sections that had ethnically much in com-

\footnotetext{
${ }^{49}$ Knaap, Kruidnagelen, pp. 133-36.

${ }^{50}$ Valentijn, Oost-Indiën, Beschr., pp. 342, 344; Knaap, Kruidnagelen, p. 135.
} 
mon with the indigenous citizenry. The Chinese citizenry was almost as rich as the VOC group, which reflects that the Chinese dominated the private economic sector in trade and craftsmanship. The settled VOC employees, the group that dominated the administration and the economic affairs of the VOC, however, was the richest.

For this presentation I intended to list the largest slave owners in the 1694 census as those who possessed at least 41 slaves, but the indigenous and Chinese citizenries did not include anyone who had that many slaves. In the indigenous citizenry the most wealthy slave owner was the captain, Jan Tsjong, with 31 slaves. He was a Christian Ambon-born Chinese, which draws attention to the fact that the leadership of this citizenry gradually came from people of Christian Chinese and mestizo origin. The most wealthy slave-owning member of the Chinese citizenry was, again, the captain, Limkitko, with 37 slaves. In the VOC group, two persons owned more than 40 slaves: first, the governor, Nicolaas Schaghen, from the small Dutch town of Wijk bij Duurstede, with the exceptional number of 92 slaves; and second, a representative of the Ambon-born mestizo class, Pieter Nuyts, who had risen to the mediocre rank of bookkeeper, with 49 slaves. The European citizenry counted five persons with more than 40 slaves, among them the captain who, with 177 slaves, was by far the richest slave owner in the province of Amboina. His name was Jochem Engel, and he was born in German Danzig, now Polish Gdansk, as was the former captain, Hans Groo, with 46 slaves. Furthermore, there was Adriaan Kakelaar with 44, born in Veere, a small town in Zeeland, one of the maritime provinces of the Dutch republic. These three were all former Company employees. There were also two rich, slave-owning representatives of the local mestizo class, both born in the nearby province of Banda but with very Dutch-sounding names. They were Jan de Ruyter and Frans Colijn, who owned 64 and 41 slaves, respectively.

\section{Conclusion}

The city of Ambon was founded by the Portuguese just after the erection of their fortress on the shores of the Bay of Ambon in 1576. It had no indigenous predecessor. As such, it is necessary to modify the image that in Southeast Asia "Manila and Batavia were the only urban settlements which were literally started from scratch by Europeans during the sixteenth and seventeenth centuries." 51 If one tries to see beyond the capital cities of the colonial empires, one has to conclude that Kota Ambon and, on the periphery of Southeast Asia, Zeelandia on Taiwan, were also created from scratch. ${ }^{52}$ We should not rule out the possibility that further research into other areas will produce more examples of this phenomenon.

On the basis of the analyses, particularly demographic, it is possible to define Kota Ambon as a Southeast Asian migrant city in which the male element was disproportionately large and the number of children relatively small. Consequently, the only way for the city to keep its numbers growing, or at least stable, was to attract new migrants. To a considerable extent, this migration was forced; for example, Company servants were simply sent on duty, or slaves were treated as commodities by traders. The slave population was by far the most numerous class in the town. Indigenous Ambonese, however, were absent in the urban population. In this period the Ambonese were still a rural phenomenon.

Political power in town was in the hands of the Dutch minority, in particular the elite of VOC servants. The institutions that governed the town were mainly of Dutch origin but

51 Blussé, Strange Company, p. 78.

52 J. L. Oosterhoff, "Zeelandia, A Dutch Colonial city on Formosa (1624-1662)," in Colonial Cities. Essays on Urbanism in a Colonial Context, ed., R. J. Ross and G. J. Telkamp (Dordrecht: Nijhoff, 1985), p. 51. 
only in so far as these did not threaten VOC rule. Consequently, one does not come across typical Dutch institutions like a vroedschap (a town council of city representatives) and mayors, recruited from the ranks of the urban bourgeois elite. Instead, the governor and his Political Council held the reins of city government. To cope with typical non-Dutch situations, however, the VOC had partly adapted the city government to local circumstances by, for example, organizing all significant ethnicities in their own citizenries and providing them with their own leadership. This practice was copied from precolonial Southeast Asian trading centers. The elite of the VOC not only ruled the town but was one of the most powerful economic groups as well because the Company was at the same time a political and an economic organization. This elite not only made the decisions concerning the trading and fiscal affairs of the VOC but also earned considerable money on the side. The second most powerful economic group was the elite of the Chinese citizenry, which more or less dominated the private sector.

As in all colonial societies race played an important role, for instance in access to power, in status, in marriage, and social stratification. The division of the non-VOC residents into European, Chinese, and indigenous citizenries draws attention to the considerable degree of formal administrative segregation. This segregation was, however, somewhat imperfect because (1) there were not enough Europeans or even mestizos to fill the ranks of the European citizenry, which consequently had to be filled with purely Asian ethnicities like Mardijkers and Makassarese and (2) the lack of European, mestizo, and Chinese women as marriage partners for European and Chinese men, who consequently had to look for partners in the Southeast Asian migrant communities and not the least among attractive female slaves. Moreover, in Kota Ambon the imperfect administrative segregation was not paralleled by a spatial one because, in general, there were no special living quarters designed for specific ethnicities.

The colonial character of the internal structure of the city can be distinguished in the political domination by an European minority. In external relations, the colonial character expressed itself in the town's function as part of a commercial and political network set up to extract resources, in this case cloves, from a subject population. Moreover, the city was the channel through which all activities of the colonizers intended to control and to penetrate the indigenous society found their way. In short, the city linked the metropolis with the colonized population. ${ }^{53}$ By the middle of the seventeenth century, the Ambonese countryside had already changed substantially. The cultivation of cloves was brought under the VOC monopoly, the indigenous political landscape was reorganized to make control for the VOC easier, and part of the population was converted from nominal Catholicism to nominal Protestantism. These changes, however, could not be attributed to Kota Ambon's urban community as the promotor of change; the colonizing VOC was, of course, not a phenomenon exclusively limited to Kota Ambon. The decisions to promote the developments were only partially taken by Victoria's authorities. Far away, the directors in the Netherlands and the High Government in Batavia also played their parts in these processes.

A comparison of the results of this analysis with literature on other Dutch colonial cities in Asia during the period of the "Ancien regime" is interesting. The outstanding pioneer in this field of studies is, of course, De Haan, with his two-volume work on Batavia. ${ }^{54}$ His work has been so impressive that it was not until the 1970s that any new studies on this

\footnotetext{
53 A. D. King, "Colonial Citics: Global Pivots of Change," in Colonial Cities, pp. 13-15.
}

54 F. de Haan, Oud Batavia, 2 vols. (Batavia: Kolff, 1922). 
subject were undertaken. It is obvious that a substantial number of the phenomena found in Batavia can be traced in other settlements as well. Generally, this holds true for the multiethnic composition of the population and the institutional structures, which always, to some extent, copied those of Batavia.

Jean Gelman Taylor, one of the authors who recently undertook to rewrite a volume on Batavia's history, draws attention to the role of the Asian-born women partners, particularly European and mestizo, of the Company servants in the field of linking "clans" in the higher ranks of the government. ${ }^{55}$ As Heather Sutherland has already pointed out, the role of these women in the struggle for power in Company circles must have been different in VOC settlements outside Batavia because the most successful VOC employees only stayed in these places for a few years. Consequently, that role should have been more manifest within the permanently settled European citizen class. ${ }^{56}$ The data for mestizo marriage patterns, in Kota Ambon, numbers of slaves, and the positions of a Jan de Ruyter and a Frans Colijn, illustrate this situation. Obviously, as Taylor stresses, the women partners of the European citizens and Company servants were to a large extent bearers of a mestizo culture, defined as a mixed culture with several European and Asian elements. ${ }^{57} \mathrm{~A}$ mestizo influence on culture, with other elements, however, should also have been manifest within the Chinese citizenry, where many Chinese men married Balinese or Makassarese women. Finally, the other migrants, such as Mardijkers and Makassarese, must have been to a certain degree culturally drawn into a mestizo orbit as well, because after becoming Christians, they must have copied European values and habits. Apart from adopting the religion, for instance, they also changed their clothing and drinking habits.

Another historian of Batavia, Leonard Blussé, presents the reader with many original points of view. His point of departure is spatial: Batavia consisted of two parts, a castle and a town, the first a cornerstone in a European trading network and the second a keystone in the Southeast Asian trading and migratory network of the Chinese. In the castle lived the Europeans, who held the political power, and in the town Blussé depicts a Chinese merchant community, which held the economic power. Demographically, the Chinese also should have been the dominant group. ${ }^{58}$ The picture of political power in the hands of the Dutch and economic power, to a large degree at least, in the hands of the Chinese was also the situation in Kota Ambon. From the point of view of demography, however, the Chinese were not dominant at all in Kota Ambon. Whether they were in Batavia, as Blussé states, depends on how one wants to interpret statistics, for it is obvious that the Chinese can only be called the dominant demographic ethnicity when slaves are not considered. When slaves are included, the Chinese amounted to only some 20 percent of the population. From Blussé's data it is not clear whether the marriage partners of the Chinese men, usually Balinese women, are included in this 20 percent. If these women and the majority of the slaves were basically of Southeast Asian origin, it is possible that Batavia, like Kota Ambon, must, demographically at least, have been a Southeast Asian migrant city as well.

\footnotetext{
55 J. Gelman Taylor, The Social World of Batavia. European and Eurasian in Dutch Asia (Madison: Wisconsin, 1983), pp. 34, 50-51.

$56 \mathrm{H}$. Sutherland, "Ethnicity, Wealth and Power in Colonial Makassar: A Historiographical Reconsideration," in The Indonesian City. Studies in Urban Development and Planning, ed. P.J.M. Nas Verhandelingen van het Koninklijk Instituut voor Taal-, Land- en Volkenkunde 117 (Dordrecht: Foris, 1986), p. 50.

57 Taylor, Social World, pp. 17-19.

58 Blussé, Strange Company, pp. 74, 83-84.
} 
VOC towns other than the capital, such as Colombo in Sri Lanka, Melaka in Malaysia, Zeelandia in Taiwan, and Makassar in Indonesia, have also attracted attention. ${ }^{59}$ Like Kota Ambon, these towns, in the second half of the seventeenth century, had populations of approximately 5,000. The article on Colombo, however, differs from the others, not only because that city falls outside the Southeast Asian setting but also because its main concern is demographic, leaving other aspects of urban history outside its focus. It describes the demographic situation of the 1694 intramuras population, which in Kota Ambon can be compared more or less with the VOC group and the European citizenry. It appears that the European and mestizo groups are similar in demographic behavior to those in Kota Ambon. ${ }^{60}$ On the periphery of Southeast Asia, the city of Zeelandia in Taiwan had a relatively short history: it was founded in 1624 and destroyed in 1662 by the Chinese warlord, Zheng Cheng-Zong. Blussé's concept of a Chinese colonial city under Dutch protection was no doubt more ideally realized in Zeelandia than in Batavia. ${ }^{61}$

In Melaka and Makassar situations similar to those in Kota Ambon and Batavia can be observed: the VOC elite held the political power and the town-governing institutions were originally Dutch but modified to the colonial situation and adapted with originally Southeast Asian phenomena such as a certain degree of autonomy for major ethnicities. The elite of the VOC played a considerable role in the economy as well. It appears, however, that the Chinese were, perhaps, economically not as strong as in Batavia or in Kota Ambon. In Melaka, they were held in check by Indians and Malays and, in Makassar, by Malays, all of them skillful trading communities that already played an important role before the arrival of the Dutch. Apparently, the Chinese did not meet an economic vacuum in these settlements. It is highly probable that in Melaka, as in Makassar and Kota Ambon, the Southeast Asians were dominant in number. On the basis of the information put forward by Andaya it is, however, rather difficult to draw demographic conclusions. Sutherland presents further detail that facilitates closer comparison. ${ }^{62}$ One of the striking facts is that the sex-ratio among the adult population in Makassar was much more balanced than in Kota Ambon. A possible explanation could be that Makassar was located in a slave-supplying area, which made the recruitment of female partners for the male foreigners relatively easy. Assuming that the majority of the slaves in Makassar were of South Sulawesi origin, one can probably conclude that Kota Ambon where all slaves had to be imported, when compared to Makassar, was a city with a much stronger migrant character.

${ }^{59}$ G. J. Knaap, "Europeans, Mestizo's and Slaves: The Population of Colombo at the End of the Seventeenth Century," Itinerario 5-2 (1981): 84-101; B. Watson Andaya, "Melaka under the Dutch," in Melaka. The Transformation of a Malay Capital c. 1400-1980, ed. Kernial Singh Sandhu and P. Wheatley (Kuala Lumpur: Oxford, 1983) 1: 195241; Oosterhoff, "Zeelandia," pp. 51-63; Sutherland, "Makassar," pp. 37-55.

${ }^{60}$ Knaap, "Colombo," pp. 88, 91-96.

61 Oosterhoff, "Zeelandia," pp. 52, 54-58.

62 Andaya, “Melaka," pp. 198-213; Sutherland, “Makassar,” pp. 41-42, 48-50. 


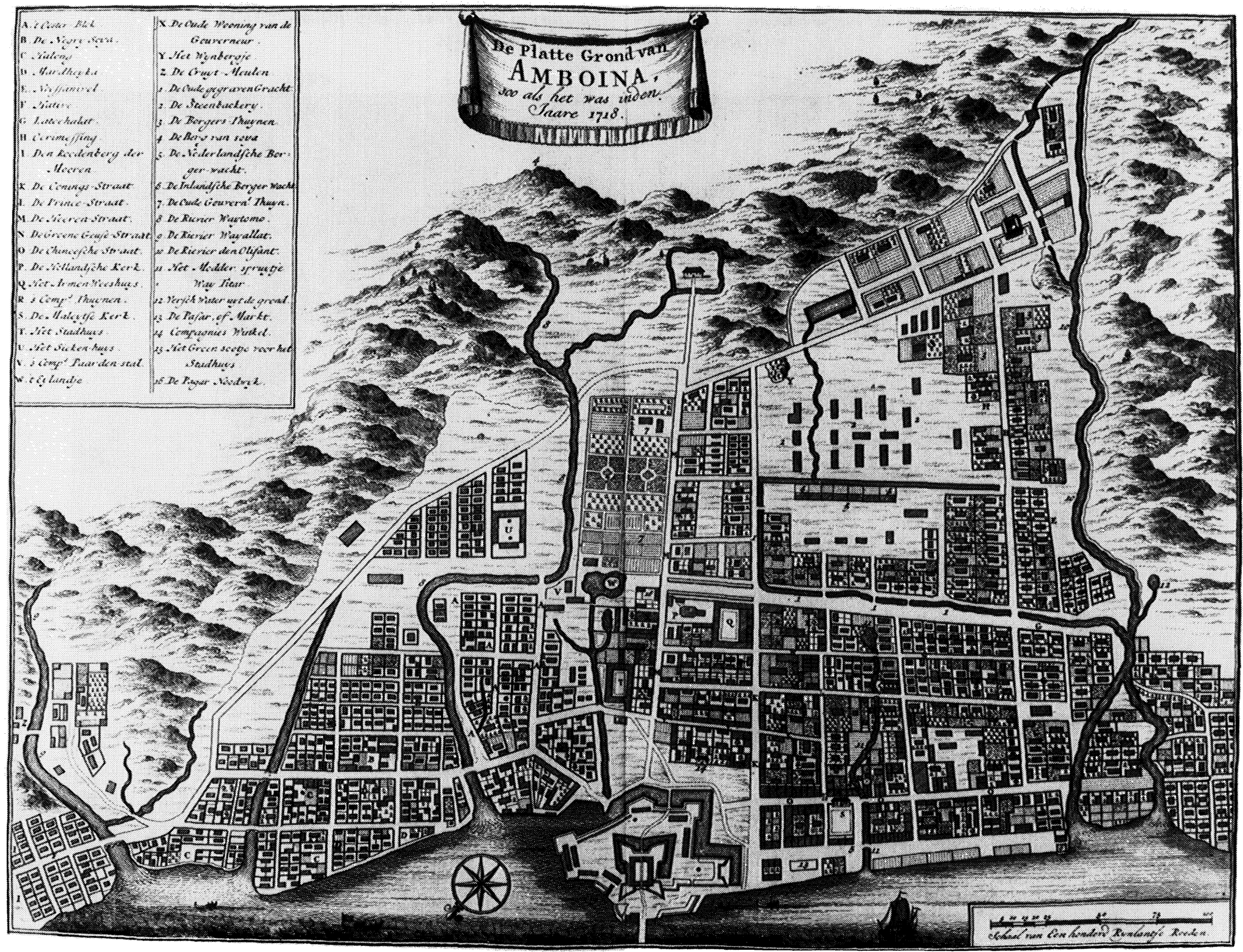

GROUNDPLAN OF KOTA AMBON in the beginning of the eighteenth century

From Fr. Valentijn, Oud-en Nieuw Oost-Indiën, vol. 2 (Dordrecht: Van Braam, 1724), Ambonsche Zaaken. 


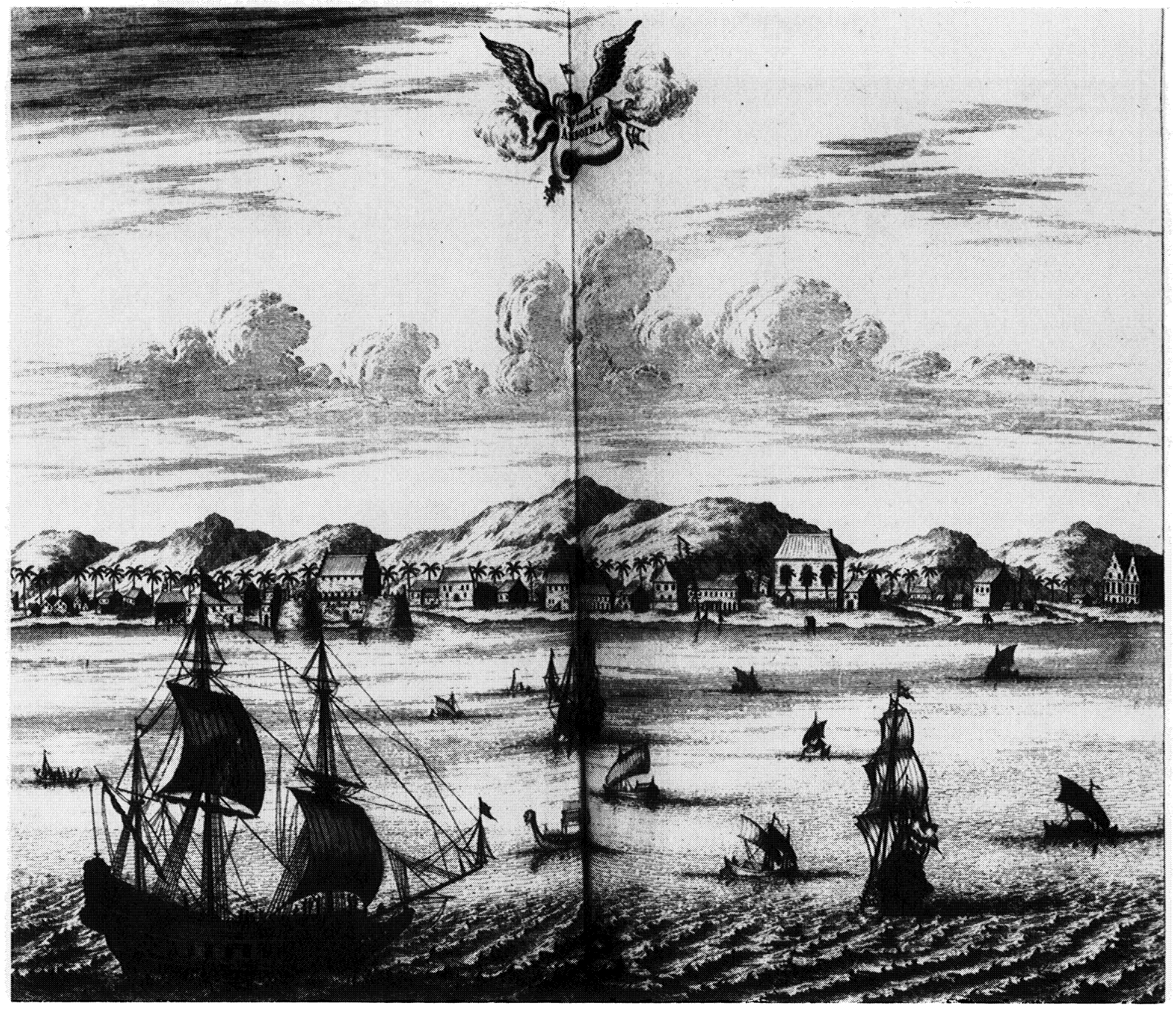

KOTA AMBON from the seaside in the $1660 \mathrm{~s}$.

From J. Nieuhof, Gedenckwaerdige Zee en Lantreize . . Oost-Indiën (Amsterdam: Van Meurs, 1682). 

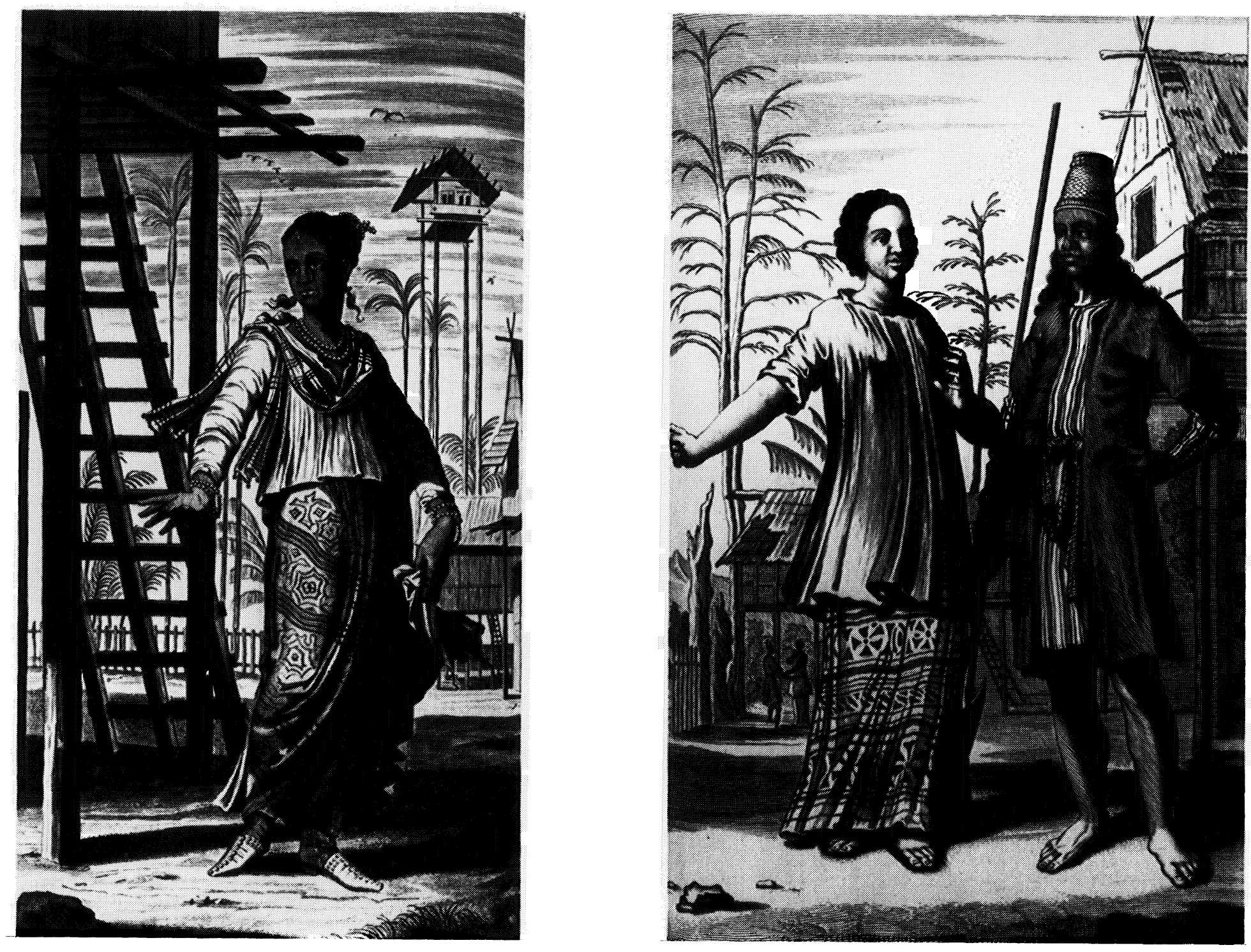

MESTIZO WOMAN.

MAKASSARESE MAN AND WOMAN.

From J. Nieuhof, Gedenckwaerdige Zee en Lantreize . . Oost-Indiën (Amsterdam: Van Meurs, 1682). 


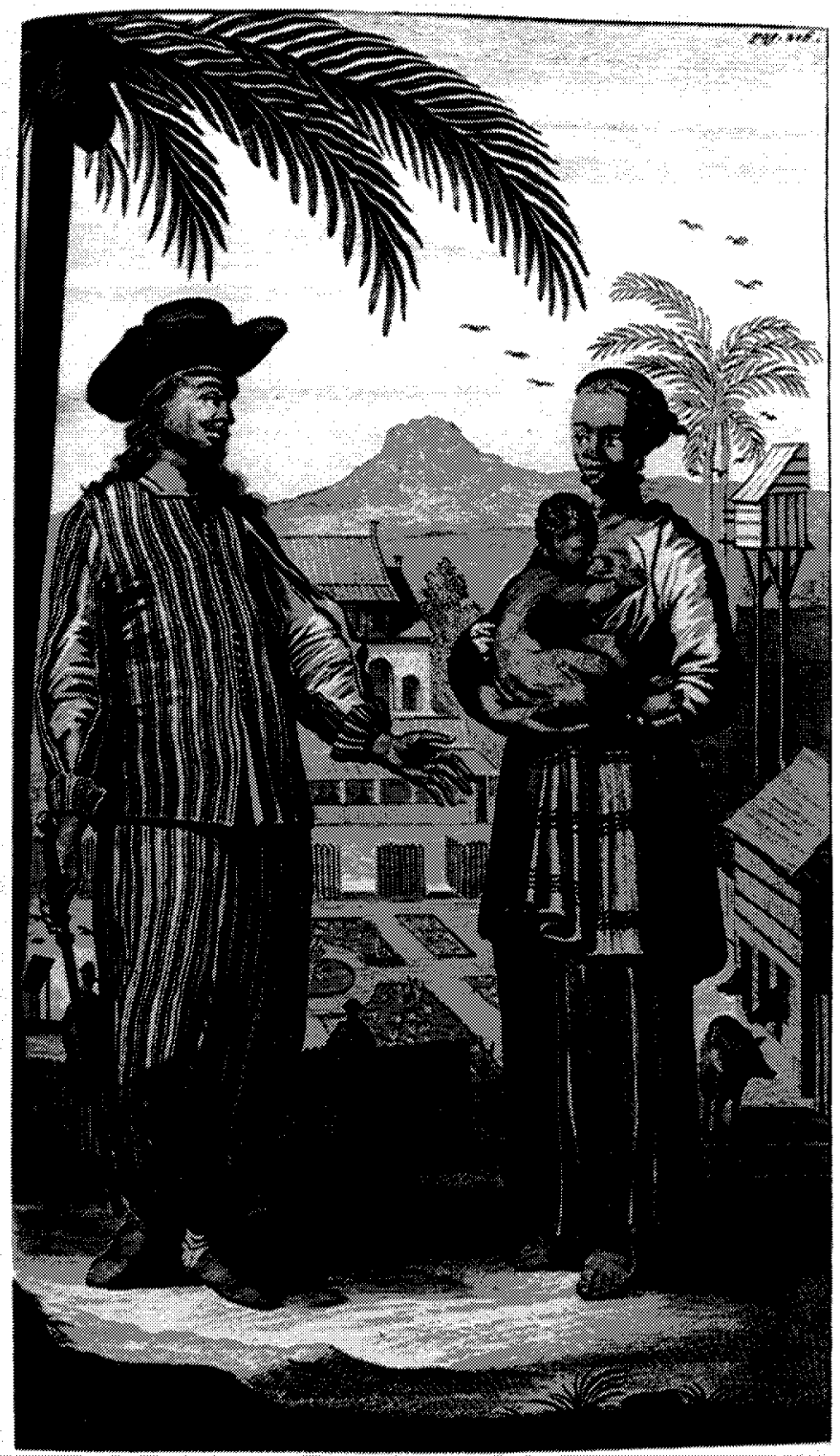

MARDIJKER MAN AND WOMAN.

From J. Nieuhof, Gedenckwaerdige Zee en Lantreize . . Oost-Indiën (Amsterdam: Van Meurs, 1682). 